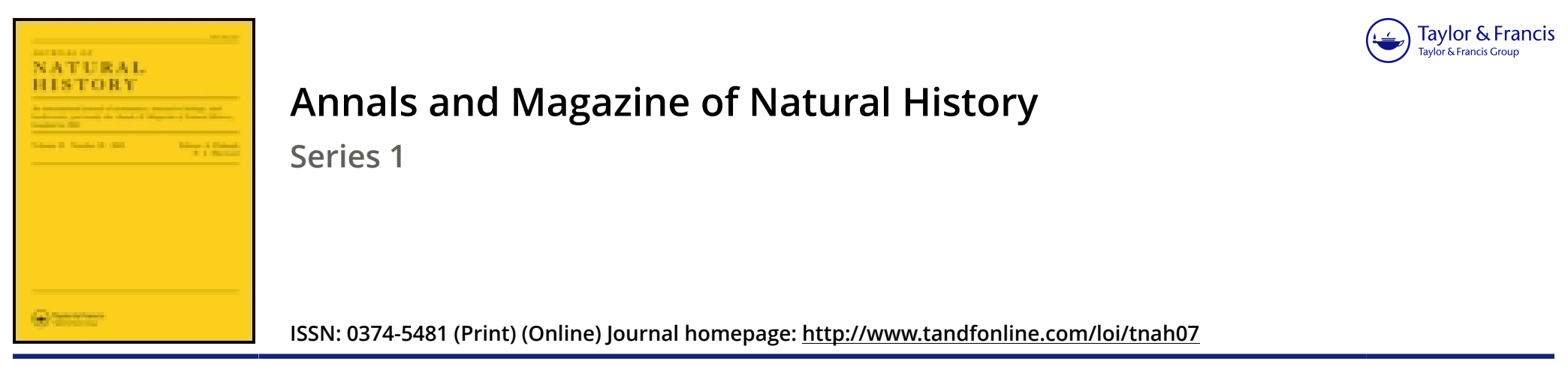

\title{
XXX.-Monograph of the Dorylidæ, a family of the Hymenoptera Heterogyna
}

\section{W.E. Shuckard Esq.}

To cite this article: W.E. Shuckard Esq. (1840) XXX.-Monograph of the Dorylidæ, a family of the Hymenoptera Heterogyna, Annals and Magazine of Natural History, 5:31, 258-271, DOI: $10.1080 / 00222934009496821$

To link to this article: http://dx.doi.org/10.1080/00222934009496821

$$
\text { 册 Published online: } 15 \text { Mar } 2010 .
$$

Submit your article to this journal $\sqsubset \pi$

Q View related articles $₫$

4 Citing articles: 3 View citing articles 진 
for it is clear, that, although Thelidomus opens the path to the Helicida, there must be several other forms between the two, either extinct or undiscovered," p. 228. -The bodies which he here describes, and the "singular discovery" which he represents as throwing an "entirely new light on this interesting question", are "actually composed of little stones and grains of sand only, agglutinated together," p. 227 and 353, and are the cases of a caddis worm which is very common in Brazil and the United States. It differs from the cases of the European kinds in being spiral; but it agrees with them in being pervious at each end, though the hole at the smaller end appears to have escaped Mr. Swainson's observation. The North American cases have been described by Mr. Lea, under the name of Valvata arenifera. It might have been supposed that the ridicule which Mr. Lea has incurred for this error, would have prevented any other naturalist from falling into the same mistake. Indeed it is difficult to understand how any one who considers the formation and structure of shells, should not have reflected on the peculiarity of the formation of these bodies before he described them, and proceeded to build up such important reasonings upon their supposed place in his system.-JoHn Eow. GRAx.

XXX.-Monograph of the Dorylidæ, a Family of the Hymenoptera Heterogyna. By W. E. SuUckard, Esq.

[Continued from p. 201.]

Sp. 6. Labidus Hopei. Shuck. Length 6 lines.

Expansion of the wings 12 lines.

Rufo-testaceus, pubescens : capite (mandibulis antennisque exceptis) atro; thorace fusco, scutello in medio sulcato, et pedunculo abdominis transverso quadrato, supra subconvexo.

Reddish testaceous, pubescent, the hair longest upon the legs, and beneath the first ventral and the whole of the terminal segments of the abdomen. The head having the vertex and face deep black and shining, the remainder castaneous, the carinæ of the face terminating gradually in front of the anterior ocellus; ocelli placed in a curve on the vertex; antennæ slender, the scape about one-fifth the length of the organ; mandibles moderately long and very slender, having but a small open space between them and the clypeus. 
Thorax subfuscous, very gibbous both in front and at the scutellum, the latter longitudinally sulcaled in the centre; superior wings with their nervures pale testaceous; marginal cell regularly lanceclate, considerably larger than either of the two first submarginals, and rounded within the first submarginal, which is rather smaller than the second, from which it is separated by an inwardly curved transverso-cubital nervure; the recurrent nervure inserted at less than one half the length of the second submarginal cell, and beyond which, and as far as the second transverso-cubital, the cubital nervure is considerably thickened : legs short and slender.

Abdomen shining, the base of all the segments constricted, the peduncle as wide as the following segment, transverse quadrate, the posterior angles truncated, plane above with a transverse convex ridge at its apex, and its ventral portion viewed laterally produced in the middle into an acute tubercle. The terminal segment vertically much compressed at its extreme apex, where it has a deep fissure, and the sexual organ protruding in the form of a deeply emarginate plate, terminating on each side in a compressed acuminated spine.

In the collection of the Rev. F. W. Hope.

This species, which was also captured by Mr. Swainson in the Brazils, is distinguished from all the rest $I$ know by its longitudinally sulcated scutellum: other prominent differences are supplied by the relative proportions and form of the marginal and cubital cells and the insertion of the recurrent nervure.

\section{Sp. 7. Lab. D'Orbignii, Shuck. Length $6 \frac{1}{2}$ lines.}

Expansion of the wings 12 lines.

Niger, brunneonholosericeus, pedunculo abdominis semicirculato supra subconvexo, nervis alarum brunneo.testaceis.

Black, covered with a close brownish silky down. Head having the ocelli small and placed in a very open curve at the vertex, and with an elevated carina connecting the posterior pair, the carinx of the face curving off and terminating in front of the anterior one; antennæ fulvous beneath, moderately long, and thickest at the base, the scape rather less than one-fifth the length of the organ : mandibles moderate, very slender, and leaving a nearly semicircular space between them and the clypeus.

Thorax very gibbous in front and at the scutellum: superior wings with the nervures brownish testaceous; the marginal cell short and broad, extending but a little wny beyond the apex of the second submarginal cell, where it is angulated; the first sulumarginal larger than the second, from which it is separated by a slightly inwardly curved nervure; the second submarginal rather narrow, and having the recurrent nervure inserted at about half its length, where immediately at the junction the cubital nervure is slightly thickened: legs short and slender, loosely covered with long hair. 
Abdomen with the base of the segments sligltly constrieted, its sides, at the junction of the dorsal and ventral plates, inclining to a bright testaceous; the peduncle nearly semicircular; the posterior angles straight, plane above, with a transverse convex ridge at its apex; the ventral portion viewed laterally produced acutely in the middle; the extreme apex of the terminal segment vertically compressed, and the sexual organ protruding in the form of an emarginate plate, the lateral portions of which form two acute and compressed spines.

In Mr. Westwood's collection.

This species is from South America, where it was captured by Mons. D'Orbigny, whose name Mr. Westwood suggested should be applied to it, which I accordingly adopt. It is the only black species I know, and the peculiarities of its small ocelli and broad marginal cell also conspicuously distinguish it.

Sp. 8. Lab. Klugii, Shuck.

Length $4 \frac{3}{4}$ lines.

Expansion of the wings 8 lines.

Rufo-castaneus, pubescens; vertice, thoracis dorso et stigmate alarum badiis: clypeo tubereulis binis acutis instructis et pedunculo transverso quadrato subconvexo.

Reddish castaneous with the vertex, dorsal portion of the thorax and scutellum, as also the stigma of the wing and the extreme base of the intermediate segments of the abdomen, dark castaneous. Head having the antennæ very long and slender, the scape scarcely one-seventh the length of the organ; the ocelli placed in a curve upon the vertex, the posterior pair situated close to the margin of the eyes : the facial carinæ less prominent than usual, and terminating by the side of the auterior ocellus; the clypeus armed with two acute and prominent tubercles, the space between which and the mandibles narrow; the latter moderate and very slender.

Thorax very gibbous in front, and at the scutellam, the latter fringed laterally : metathorax slightly convex : superior wings with their marginal cell regularly lanceolate and rather larger than either of the two first submarginals; the radial nervure rounded and not angulated; the first submarginal rather larger than the second, the transverso-cubital nervure that separates them being straight; the recurrent nervure received at about one half the length of the second submarginal cell, and the cubital nervure beyond its insertion not thickened : legs very short and slender.

Abdomen with the base of the intermediate segments slightly constricted: the peduncle rather narrower than the following segment, transverse quadrate, the posterior angles slightly rounded, plane above, with a slight convexity in the centre of its apex; the apex of the terminal segiment less vertical than usual, but much compressed and fissile; the sexual organ protruding in the form of a deeply emarginate plate, 
the sides of which are acuminated in two prominent teeth, and beneath from the emargination it is canaliculated. In my own collection.

This species is from St. Vincent's in the West Indies, where it was collected by the late Rev. Lansdown Guilding, from whose collection I purchased it. It is remarkably distinguished from all the others by the two teeth of the clypeus and the length and slenderness of its antennæ, besides other differences.

Sp. 9. Lab. Romandii, Shuck.

Length $4 \frac{1}{2}$ lines.

Expansion of the wings 7 s lines.

Rufo-testaceus, subpubcscens: vertice badio, stigmate alarum brunneo-fusco et pedunculo abdominis quadrato convexo.

Reddish testaceous, subpubescent. Head having the vertex dark castaneous, on which the ocelli are in a curve and very large, the posterior pair placed rather laterally and near the margin of the eyes; the facial carina snrall and rounding off to the sides of the anterior ocellus : antennæ moderately long, the scape very short, the flagellum not thickest at the base: mandibles short and slender, leaving but a small narrow space between them and the clypeus.

Thorax slightly gibbous in front; the scutellum not gibbous, rather flattened above: metathorax rounded : superior wings with their nervures very slender and brown, the stigma dark brown: the marginal cell lanceolate, larger than either of the two first submarginals, and slightly acuminated beyond the apex of the second, which is less than the first, from which it is separated by a nearly straight transverso-cubital nervure; the recurrent nervure inserted in the centre of the second submarginal cell, and the cnbital nervure thickened merely at the junction: legs short and slender.

Abdomen with the base of the intermediate segments constricted, the terminal ones slightly compressed; the peduncle quadrate, slightly convex, narrower than the second segment, which is also a little narrower than the third; the two last segments slightly laterally compressed, and the apex of the terminal one very much compressed and fissile: the sexual organ protruding as usual.

In my own collection.

'This species was also captured by Mr. Swainson in the Brazils. I have dedicated it, as a small tribute of respect, to Mons. de Romand, an ardent lover of the Hymenoptera, whose rich collection would, I expect, yield other species had I the opportunity of examining it. The present is singularly distinguished by the form of the peduncle, the compression of the segments, and the proportionate differences between the second and third: its small mandibles are also of a very peculiar character.

? Sp. 10. Lab. mediatus, Fab.

Niger thorace arcu antico cinereo, abdomine rufo: petiolo anoque nigris.

Dorylus mediatus, Fab. Sys. Piez.428. 3.

Habitat-in America meridionali, Dom. Smidt. Mus. Dom. de Sehestedt. 
Media. Antennæ nigræ: articulo secundo basi ferrugineo. Caput nigrum, labio cinereo villoso. Thorax niger, arcu antico cinereo. Abdomen rufum, petiolo anoque nigris. Alæ obscuræ.

Latreille and St. Fargeau have surmised, from the country of this insect, and from Fabricius having associated it with his Doryli, that it must be a Labidus. I think, however, both from the distribution of colour and his description of the labium (labrum), that it cannot belong to either of these genera ; but what it may possibly be I cannot at all surmise.

N.B. Dr. Maximilian Perty, in the 'Delectus Animalium Articulatorum' of the Brazilian 'Travels of Spix and Martius, has figured in plate 27, fig. 11, a Labidus which he calls Lab. Latreillii, and at p. 138 he thus describes it :-

Totus badio-testaceus, albido-pubescens; ocellis magnis, hyalinis; alis albis, nervis flavicantibus.

Length 7 lines, width of prothor. $1 \frac{1}{2}$ line. Expansion of the wings 16 lines.

He says it occurs in the province of Piauhiensi and in Southern Brazil.

It is very probable that this is a distinct species, or that the species from each of these localities are different, but without a careful examination it is impossible to say. If however they are both of the same size, and the expansion of the wings is the same, they are doubtlessly identical ; the proportions between the expansion and the length differ so considerably from any that I have described, and as by a comparison with the description of the genuine $L a b$. $L a$ treillii above it appears evidently different from that, I therefore propose to call it

? Sp. 11. Lab. Pertii, Shuck.

Lab. Latreillii. Perty, Del. An. Art. Tab. 27. fig. 11.p. 138.

\section{Genus Trphlopone, Westw.*}

Head oblong, convex, emarginate behind, occasionally longitudinally sulcated, and nearly as long as the thorax, not exhibiting either eyes or ocelli.

Antenna about as long as the head, inserted within two short parallel facial carinæ, and close to the anterior margin of the clypeus, geniculated and subclavate, consisting apparently of only ten joints; the

* Mr. Westwood has neither given a generic nor specific description of what he calls Typhlopone fulva; he has only given an outline of the insect, and of its maxilla and labiun and their palpi, and described the mandibles. See Introd. to Mod. Class. of Ins. vol. ij. p. 226. fig. 86, and the descriptions at p. 219. And he has not noticed the remarkable structure of the antenme, apparently wanting two joints. 
scape clavate, nearly as long as the flagellum, which is also clavate; the terminal joint half as long as the scape, the intervening ones short and subequal.

Mandibles sickle-shaped, serrated? along their inner edge. Westw. Maxillary palpi short and two-jointed, the joints subglobose. Westw. Labial palpi longer, also two-jointed, the joints subclavate. Westw. Mentum subtrilobate in front. $W_{\text {estw. }}$.

Thorax oblong, much narrower than the head, with a deep transverse suture separating the meso- and metathorax, the latter with a large circular spiracle at its base above. Legs simple, thighs subclavate; tibic slender at the base, increasing slightly towards the apex, where they are all furnished with a simple calcar, which is somewhat dilated at the base; tarsi slender, longer than the tibix, the terminal juints of the anterior slightly dilated, ali the terminal claws simple.

Abdomen elliptical; the basal segment quadrate convex, forming a peduncle, and separated from the next by a deep incision; the ventral portion acutely produced, the following slightly constricted at their base, and all exhibiting laterally a conspicuous spiracle; the terminal segment abruptly truncated or subretuse at its apex, the dorsal portion armed laterally with two minute spines, and the ventral with a single one.

It is here requisite that $I$ should state my reasons for considering the three following insects as probably the females of the genus Labidus. In the absence of any observation relative to their habits, my arguments must necessarily all be derived from structure; and deduced from this I still admit that there is one, and only one, point that makes me waver in my supposition. Sexual discrepancies are universal throughout the Heterogyna, for it is rarely the case that the partners resemble each other, therefore those differences here must not startle us. In the preliminary observations I have already shown that the males, the only sex accurately known of the genera of this family, possess characters found partially in the Solitary and Social Heterogyna, but conjunctively nowhere excepting in themselves, and upon this I establish a claim for their constituting a family intervening between both. In these apterous insects (Typhlopone) I can exhilit a similar combination, which consequently proves that they necessarily belong also to this family. In the form of the head they are most closely like the female Scleroderma*,

* I am prepared to show from the analogy of one of the Thynnida, of which I have both sexes taken in copulat, (the female of which is the Diamma ephippiger of Guerin, and the male a Rhagigaster of the sane author,) that Scleroderma belongs to the Solitary Heterogyna, and not to the Bethylidee as supposed by Mr. Westwood in his Monograph, and that the males he has described as belonging to them are certainly misplaced. There is every probability that what is usually considered as the Myzine of Latreille, but which is the Elis of Fabricius, are the true males of Scleroder$m a$, there being no European species of the genuine Myzine, which is the 
and in the anamolous limitation of the number of joints of the antennæ, they resemble Myrmecodes and the rest of the apterous Thynnida, although in the latter there is one joint more to be seen than in these, viz. eleven. This curtailment is never found in the apterous Social Heterogyna, to which however the single calcar to all the tibiæ, and their wanting eyes, approximates them, and I have before stated that in the armature of the apex of the abdomen they much resemble Ponera. They thus partake of both groups, but they have this peculiar to themselves amongst the apterous Heterogyna, viz. the small development of the prothorax, which cannot be seen from above, and the large development of the mesothorax at the expense of it; now in the apterous individuals of both the adjacent groups, the Social and Solitary Heterogyna, we find either a very large development of the prothorax or an equal one of both pro- and mesothorax; and in their males either the three divisions are equal, or the meta- and meso- are equal and more fully developed than the prothorax; but where the meso- and metathorax are unequal, it is the latter which is most developed. In the male Dorylida we also find an enormously developed mesothorax, and the prothorax rarely observable from above; to these they are likewise closely linked by the two-jointed palpi, the size and conspicuousness of the lateral spiracles of the thorax and abdomen, as also by the insertion of the antennæ near the edge of the clypeus. To Labidus especially do they appear connected, by the carinæ of the face, the dilatation of the base of the calcaria, the proportions of the labial and maxillary palpi, and the form of the mandibles, the latter differing no more than might be expected in the opposite sex. The slight constriction of the segments of the abdomen appears also a connecting resemblance. If from the preceding argument it is admitted that these apterous insects must belong to the Dorylida, and from analogy we may infer that they are females, and when we know that their country is America and the West Indies, and that none but females have yet occurred, and when it is further considered that there is a genus of the same family from the same country of

Plesia of Jurine, the type of it being the Tiphia maculata; Fab. Besides this I am acquainted with genuine males of these Plesice which closely resemble their females, and are totally different in structure from the Elis sexcincta, Fab., the type of his genus Elis, and which has been latterly usually considered as the Myzine of Latreille. Were the females of this genus Elis winged, as several species of the male occur in the South of Europe, it would be strange that the female should not have been captured ere this. Sidney Smith Sanders, Esq. has informed me that he finds several species of Scleroderma not uncommon in Greece, where also he has found more than one species of the male Elis, and for one species of each of which I am indebted to Jim. 
which we only know the males, and when I have also shown that there are as many structural resemblances as might be expected, or is usual between the opposite sexes of these anomalous groups, surely it is not presumptuous to suppose, in the absence of positive testimony, that these may be the sexes of the same genus. The solitary point which still causes me at all to doubt it, is the minute tooth beneath and within the apex of the claws of the males of the genus Labidus, although it is scarcely obvious in the smaller species of that genus; therefore in these small females, which are much smaller than the smallest males, this tooth may become obsolete. The disparity of size in the sexes, I have before stated in the preliminary observations, is no objection to the hypothesis. I proceed accordingly to describe them as Labidi.

Sp. 12. Lab. (1 Typhlopone) Kirbii, Shuck. Length of the head I line. Probable length $4 \frac{1}{2}$ lines.

Capite castaneo nitido punctulato, antice subsulcato, mandibulis badiis. Head bright chestnut, shining, very slightly and loosely punctured; slightly longitudinally channeled in front, but which terminates abruptly in a small fossulet at about one-third the length of the head: without eyes or ocelli. Maudibles dark pitchy chestnut, flagellum of the antennæ also obscure.

In my own collection.

Of this insect I have only the head, which is attached to the thigh of a Formica; to judge from the size of this head and the comparative proportion to the whole insect in other species, this would be the largest. I dedicate it with much respect to the venerable promoter of the science of Entomology in this country, whose. Monographia Apum Anglia will ever remain a standard of high perfection.

Sp. 13. Lab. (2 Typhlopone) Curtisii, Shuck.

Length about foir lines.

Rufo-testaceus, glabratus; capite punctulato, postice profinde sulcato; mandibulis badiis.

Reddish testaceous. Head brightly shining, punctulate, deeply sulcated longitudinally in the centre behind, the cliannel terminating near the centre of the head in a moderately large fossulet: without eyes or ocelli ; mandibles pitchy-brown.

Thorax opake, more closely and deeply punctured than the head.

Abdomen brightly shining, very slightly punctured, the peduncle quadrate, opake and convex, the third and fourth segments slightly constricted at their base, the apex of the terminal segment abruptly truncated and armed on each side with a minute spine.

In the collection of the British Museum.

This insect is distinguished from the preceding by its smaller size and by the deeper sulcation appearing only on the vertex. It 
is dedicated to John Curtis, Esq., the author of the British Entomology, in which work the portions devoted to the Hymenoptera were evidently a labour of love.

Sp. 14. Lab. (3. Typhlopone) Westwoodii, Shuck. Length 3 lines.

Testaceus; capite (mandibulis piceis exceptis) castaneo nitido, valde punctato et in medio sulcato.

Pale reddish testaceous. Head bright chestnut, shining, rather closely and deeply punctured, deeply sulcated longitudinally above in the centre, the channel dividing the head into two halves; mandibles pitchy red.

Thorax more closely and deeply punctured than the head, and about its length.

Abdomen brightly shining, scarcely punctured, the peduncle quadrate, opake, convex, the vertral portion produced into an acute tubercle, the following segments slightly constricted at their base, the apex of the terminal one subretuse, armed on each side with a minute spine, and its ventral portion also furnished with a minute central spine.

In my own collection.

From South America. Its distinction from the two preceding consists, exclusive of size, in the entire longitudinal sulcation of the head.

Body elongate cylindrical.

Genus Anrctus, Shuck.

Head small, transverse, flat.

Antenna short, setaceous, curved, inserted upon the anterior margin of the clypeus, and not quite so long as the insertion of the superior wings, the scape about one-third the length of the flagellum, the joints of the latter equal.

Eyes globose, lateral, and very prominent.

Ocelli placed in a slight curve upon the vertex, large and very prominent. Mandibles edentate, elongate, slender, compressed, very much curved, slightly broader at the base, and forcipate.

Labrum truncated at the apex, where it is emarginate in the centre.

Maxilla

$\left.\begin{array}{l}\text { Maxillary palpi } \\ \text { Labial palpi }\end{array}\right\}$ ?*

Thorax short, oval : collar or prothorax more developed than in Dorylus, and not concealed in front by the gibbosity of the mesothorax : scutellun quadrate, very gibbous, slightly projecting over the metathorax, which is perpendicular.

Tegule small but distinct.

Superior wings with a large stigma, one acuminated, marginal cell angu-

* The internal trophi I am obliged to pass over, but as they are scarcely distinguishable in the large species of Dorylus, in a small insect like the present, which is at least fifty times less, the investigation would incur a certainty of destruction without possibly effecting the object; but it is quite sufficiently distinguished by its more obvious characters. 
lated within, and two submarginal cells, the first of which is smaller than the second, and receives the recurrent nervure at nearly threefourths of its length.

Legs short and slender: coxe robust, canaliculated above for the articulation of the femur: trochanter not distinct : femora and tibice slender and subcylindrical, the latter furnished at their apex with a single calcar : tarsi slender, longer than the tibix, the basal joint as long as the three following, the fourth joint the shortest: the claws simple.

Abdomen elongate, curved downwards, cylindrical and slightly clavate; the dorsal segments, but especially the terminal ones, slightly constricted; the penultimate segment much shorter than the antepenultimate, and forming merely a transverse slip; the first segment, which forms the peduncle, quadrate, the angles rounded; above deeply channeled down the middle, which gives it a bilobate appearance, beneath carinated and flattened laterally from this carina : the apical segment obtuse and rounded.

Type of the genus REnictus ambiguus, Shuck.

Named from its ænigmatical structure, which participates in that both of Labidus and Dorylus, from the latter of which, although the neuration of the wings is nearly similar, other parts differ so much, especially the mandibles, prothorax, peduncle of the abdomen and legs, that it would not consistently associate with it, and in all these particulars it completely agrees with Labidus, forming a link between the two genera which thus corroborates their affinity*, although their generic disparity is strongly substantiated by the comparative conformation of the male sexual organ, which, as in Dorylus, here also has the fornicate lateral valves (the external sheath), which are also fimbriated at their apex. The central process (penis), however here takes the same curve, but higher than these valves, which closely embrace it laterally, and are not more than three-fourths as long as it; this central portion forms, viewed from above, a double parallel tube, separated by a.narrow fissure at its extreme apex, but afterwards joined by membrane : the representative of the inner sheaths take here a very different form from what they present in Dorylus, for here they are fornicate, excised just within their apex, they then become suddenly dilated, terminating abruptly in an obtuse angle, which points downwards. The horizontal furcate plate beneath is very broad and quadrate, the furcation being formed by two slender acuminated converging spines. This remarkable insect is a na-

* St. Fargeau hints a doubt of this, where be says, "Je ne présume pas, en l' absence du sexe féminin, quelle peut être leur' place définitive, et, du reste, l'analogie apparente me porte à les laisser avec les Dorylus, et à les placer ici hors de rang, en attendant des éclaircissemens sur leurs mœurs." 'Hist. Nat. des Hymenop.' (Suites à Buffon), tom. i. p. 227. But this author has made many mistakes throughout his notice of these genera, and his opinion of them consequently is not at all to be trusted. 
tive of India, and thus binds the forms of the Old and the New World together. The genus is, however, as yet incomplete, as I only know male individuals.

Sp. 1. AErict. ambiguus, Shuck.

Length nearly 4 lines. Expansion $7 \frac{1}{2}$ lines.

Rufo-testaceus, pubescens: capite (antennis, mandibulisque exceptis) et thorace nigro.

Reddish testaceous, covered with a close silky down; head, with the exception of the antennæe and mandibles, which are of the same colcur as the body, black and shining; ocelli placed upon an eminence on the vertex, in a curve; mandibles very long, much curved, somewhat broadest at the base, pubescent externally, and when closed leaving a wide space between them and the clypeus, upon the anterior margin of which the antennæ are inserted in a cavity, the inner carinated edges of which join in the centre of the face, forming a single carina, which extends to the anterior ocellus. Antennæ rather robust, equally thick throughout, the scape not thicker than the flagellum and about onethird its length.

Thorax black, or sometimes pitchy, covered with a close decumbent down, convex, very gibbous at the scutellum, which is quadrate: superior wings with the nervures and stigma brown; the tegulæ testaceous; legs short, slender, testaceous, and covered with long loose hair.

Abdomen testaceous, covered with close decumbent down, with the peduncle wider than the second segment, deeply canaliculated, and of the shape of a saddle reversed, rounded at the base; the terminal segment rounded and obtuse.

Col. Sykes's collection.

A native of Poonah in Bombay, whence it was brought by Lieut. Col. Sykes. I have above amply dilated upon its extremely anomalous structure. The female unfortunately is not known.

\section{Genus 3. Donyuus, Fab.}

Vespa, Lin. Mutilla, Lin., Christ.

Body elongate, cylindrical, more or less pubescent.

Head small, transverse, flat, the face sometimes swollen.

Antennce sliort, setaceous, curved, the scape long and siout, inserted near the anterior edge of the clypeus within the inner angles of the mandibles; the scape and flagellum varying considerably in their relative proportions, the former rarely one-third the length of the whole organ, the apex of which rarely extends to the insertion of the superior wings.

Eyes moderately large, globose, very prominent and lateral.

Ocelli placed in a triangle on the vertex, very large and prominent.

Mandibles edentate, much compressed, forcipate, convex externally, and concave within, variable in form and proportion.

Labrum semicircular, occasionally tuberculated and shutting down upon and inclosing the remainder of the trophi. 
Maxilla obsolete?

Maxillary palpi two-jointed, the joints minute, subglobose, abruptly truncated, the terminal one rather the smallest, both having divergent setæ at their apex.

Labial palpi two-jointed and in advance of the maxillary, than which they are rather longer, the basal joint subobconic, the terminal one minute and subulate, and both with divergent setæ at their apex.

Mentum waved laterally and emarginate in the centre.

Labiun membranous, triangular.

Thorax subcylindrical, very gibbous at both extremities.

Prothorax extending laterally to the insertion of the anterior wings.

Mesothorax largely developed, advanced considerably beyond the insertion of the anterior wings, gibbose in front and suspended over the prothorax.

Scutellum large, usually transverse, gibbous, rounded at the apex.

Metathorax not largely developed.

Tegule small, slender, and linear, but distinct.

Superior wings not so long as the abdomen, with one marginal and two submarginal cells, the first of the latter much longer than the second, and receiving the single recurrent nervure usually near its niddle.

Iiegs short: coxce large, convex benenth and concave above: trochanters triangular : femora quite glabrous and shining, very much compressed, usually triangular and broadest at the base: tibie smooth, shining, slender, not so long as the femora, and furnished at the apex with a single calcar, at the insertion of which there is usually a coronet of small spines : tarsi longer than the tibiæ and very slender; the basal joint as long as the three following, the fourth the shortest, and the fifth terminal joint supplied with a pair of short stout sinple claws, and having a moderately large pulvillus between their fork.

Abdomen elongate, cylindrical, frequently slightly clavate towards the apex, where it curves downwards ; the first segment variously formed and separated from the following by a deep incision, forming a sort of peduncle always convex above : the penultimate and antepenultimate segments equal or subequal: the male sexual organ frequently protruding.

Type of the genus Mutrula Helvola, Lin.

This genus is restricted to the old world, and its metropolis appears to be Africa, from the southern extremity of which one species, the type, comes in considerable plenty, which renders it strange that nothing should come with it that might with any probability be associated as the female. But if my assumption should be right as regards the female of Labidus, the supposition is that it also has a blind female which never or rarely quits its subterranean abode.

The generic differences throughout this family are strongly confirmed by the structure of the male sexual organs, which have also specific diversities, and thus here obtain a value not usually acceded 
to them in the description of insects*. The Rev. Mr. Kirby said, many years ago,- " The head and its organs are in some degree analogous to the root in plants, for they collect and absorb the nutriment; the truncus may be looked upon as representing the stem, the limbs the branches, the wings the leaves, the abdomen as a kind of calyx, including the fructification. Therefore the great command, ' increase and multiply,' will direct us to those parts which constitute the essence of an insect." He next says in continuation, " but these, if it were possible, it would be improper to use for characters." I introduce them here certainly not as characters, but in confirmation of less tangible characters, thus proving the efficiency of the latter, and as a small contribution to the description of the comparative structure of these organs in insects, which comparative anatomists may not always or even frequently have the opportunity of examining.

In Dorylus helvolus this organ consists of two large fornicate valves (the external sheath of the penis, Burm.) which are fringed at their apex; within the fornix, and springing from the centre of its base, there is an elongate linear process (the penis) deeply longitudinally channeled both above and beneath, and which extends to the apex of the valves opposite their central division: this division reaches nearly to their base, where these valves have a common origin, and this base forms on each side beneath a convex return, with which an elongate compressed spine (the inner sheath) articulates, having a vertical motion; and these spines curve upwards on each side of the central canaliculated process near its base, where it is also articulated. At the extreme base of this complex organ, and articulating with it beneath, there is a horizontal flat linear plate deeply furcate at its apex, the furcation half the length of the plate, which also extends to the apex of the two large superior lateral lobated valves.

It is a circumstance worthy of remark, that wherever I have had the opportunity of examining and comparing several individuals of a species throughout the family, I have found so great a uniformity of size that $I$ have not detected a difference of half a line even among the larger ones. Thus although the characters that separate them are sometimes very obscure, and without patient examination elude discovery, my experience seems to support an opinion that wherever great differences of size are found between specimens of these genera, the presumption is, that characters exist which will individualize them, although too recondite for instant detection, yet so tangible when found as not to admit of the least doubt of their specific value,

* Monog. Ap. Angliæ, vol. i. p. 39. 1802. 
and which become corroborated, as I observe above, by the form of the male sexual apparatus. The species in the present genus seem to separate themselves into groups, for there is less uniformity of general structure than is commonly found in a natural genus, and the form of the peduncle of the abdomen appears in some degree to influence the form of other parts. The groups they resolve themselves into are these, which may be thus characterized by the form of the peduncle alone or in conjunction with the mandibles, viz.:

1st. Peduncle cup-shaped, nearly as large as the following segment. Sp. 1.

2nd. Peduncle cup-shaped, much smaller than the 2nd segment. Sp. 2. and 3.

3rd. Peduncle quadrate, mandibles slender and much acuminated. Sp. 4, 5, 6 .

4th. Peduncle quadrate, mandibles broad and nearly triangular. S.p. $7,8,9,10$.

Sp. 1. Dor. nigricans, Illiger. Length 13 lines. Expansion 21는

Nigricans, brunneo-lolosericeus, abdominis petiolo acetabuliformi, segmento secundo paulo minor.

Illiger, Mag. der Ent. $1^{\text {tex }}$. Bd. Seit. 188. 18.

Fabricius, System. Piez. 427. 2.

Latreille, Gen. Crust. et Ins. 4, 124.

-, Nouv. Diction. d'Hist. Nat. $2^{\mathrm{e}}$ ed. 9. 556.

Blackish brown, velvety, elongate cylindrical : head comparatively large, slightly convex towards and beneath the vertex; the ocelli are comparatively small and are placed in a triangle; eyes lateral, small, ovate convex : antennæ short, setaceous, the scape rather more than onethird the length of the organ ; mandibles elongate, narrow, much acuminated, and with the antennæ and legs of a dark castaneous.

Thorax very robust, covered with a bright brown silky pubescence, with two abbreviated longitudinal central lines in front : scutellum slightly gibbous, broad : superior wings with their nervures blackish, and the surface clouded with brown, the recurrent nervure inserted just within the centre of the second submarginal cell, the cubital nervure extending straight to the angle of the second submarginal : femora elongate, triangular, subacuminate at the apex.

Abdomen cylindrical, blackish brown, the margins of the segments a little paler : the peduncle cup-shaped above, villose beneath, nearly as large as the second, the terminal smooth and abruptly truncated at its extreme apex, which is a little reflected.

In most Collections.

This remarkable species, which in the size of its head and peduncle and smallness of its eyes differs from all its congeners, is from Sierra Leone.

[To be continued.] 